\title{
Mapping Swabian migration in the 18th century to NW Romania (Sathmar county)
}

\author{
Dr. Maria BOȘTENARU DAN, researcher \\ „Ion Mincu” University of Architecture and Urbanism, Faculty of Urbanism, \\ Department of Urban and Landscape Design \\ Maria.Bostenaru-Dan@alumni.uni-karlsruhe.de
}

\begin{abstract}
The paper presents field and literature investigations to the places of origin and end for the Swabian migration in the 18th century, from the space between Ulm and Lake Constance to the NW Romania (Sathmar county). Soon after the departure of the Swabians, the place was marked by some of the most notable Baroque religious architecture, built heritage today. In the new home, the count of Károly let churches be built, some of which were destroyed totally or partially in the 1834 Érmellék earthquake. Long term goal of this research is to map this gradual construction and reconstruction with the methods developed by the author in a larger project.
\end{abstract}

Keywords: 18 th century, earthquake impact, mapping

\section{INTRODUCTION}

The paper investigates the way a digital model of the impact of the 1755 earthquake on Lisbon developed previously (Bostenaru and Panagopoulos, 2013) can be adapted to the situation faced by Swabians migrating from South-West Germany to Transylvania. Such one may regard the impact of the 1834 earthquake on the Sathmar area, where some of these settled. We intend to adapt the digital model developed for an urban area (the interwar centre of Bucharest, Fig. 1, see methodology in Bostenaru and Armaș, 2015) to a geographic region.

Karlsruhe celebrated in 2015, 300 years since foundation. 3 years before, Danube Swabians celebrated also 300 years since immigration to Eastern parts of Europe. Both events are in the $18^{\text {th }}$ century, which was marked by the Lisbon earthquake, which made a shift in understanding of catastrophes also including a philosophical and humanities point of view, in the age of Illuminism. Therefore, the period presented at the city manifestations on the $300^{\text {th }}$ anniversary of Karlsruhe has built an excellent basis to investigate the historical conditions of Swabian migration. Field trips accompanied the investigation, and a book of the author on the Lisbon earthquake (Boștenaru and Panagopoulos, 2014) was discussed with knowledgeable librarians. Several years ago, in 2005 , the $250^{\text {th }}$ anniversary of the Lisbon earthquake was an occasion for Europe wide events, not only in Portugal but also under the auspices of Academia Europea at the Geoforschungszentrum in Potsdam. On this occasion the engravings, which were later replaced by photography in the history of disasters, such as the ones contemporary with the one considered for this research, were presented. While the images of disasters in drawing have been the subject of many projects, the history in photography is ongoing and few initiatives are known, one being a doctorate at the State School of Design Karlsruhe, in association with the Centre for Art and Media (ZKM), by Jacob Birken. Investigation in the library of the State School of Design will continue this research. The ZKM museum in Karlsruhe is a unique museum in the world for digital art and digital art conservation. Karlsruhe has a strong tradition in investigating and implementing digital methods, and this is relevant for some of the methods used in this research. 

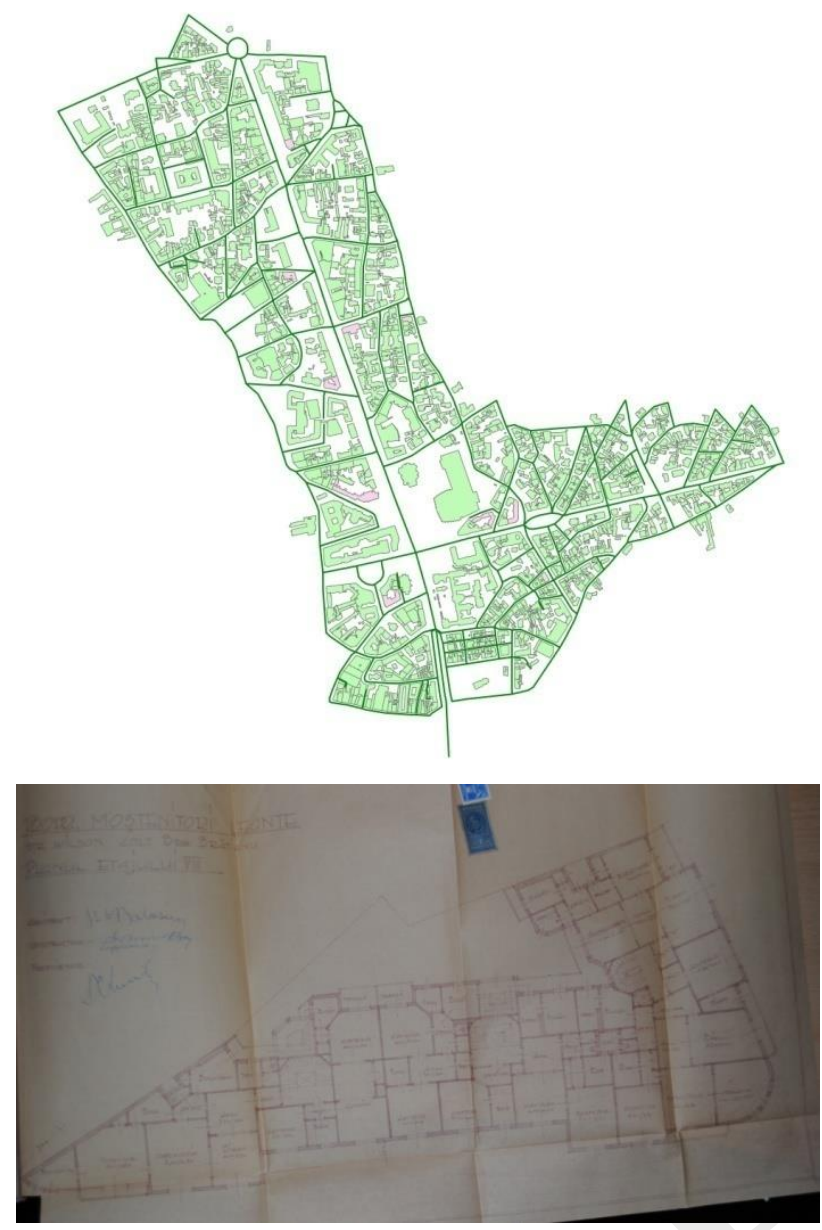

Figure 1. Overview of scales at urban level on Bucharest, Magheru boulevard (within built protected zone 04 http://www.pmb.ro/servicii/urbanism/zone_protejate/doc s/bratianu.pdf): the collapsed buildings in a GIS application (in pink) and one such collapsed corner building (Wilson building) in an archive drawing.

The research on the Swabian heritage was started in frame of a POSDRU structural funds funded project at the University of Bucharest with field trips in the Sathmar area, finalised with a conference communication (Bostenaru, 2014), and to Germany, Karlsruhe (see acknowledgements). The research is currently continued with a DOMUS scholarship of the Hungarian Academy of Sciences (https://sites.google.com/view/domusszulofoldioszt ondij/home), which funds some more field trips to both areas. 2018 is the European Year of Cultural Heritage and under these auspices the Europeana online archive is researching stories of migration, see at https://www.europeana.eu/portal/de/collections/ migration, where the author submitted family stories (https://www.europeana.eu/portal/de/record/208400 2/contributions_7f32d500_b664_0136_e11c_6eee0 af68b02.html?q=bostenaru\#1543670064599)

regarding the region investigated in this article.

\section{STUDY AREA AND RESEARCH BACKGROUND}

The area proposed to be investigated is that of the German settlement around the city of Carei, in Sathmar county, Romania. In this area, Swabians (Germans) settled starting 300 years ago (2012 was the anniversary). Literature on their stepwise settlement has been consulted. Carei was the headquarter of a mighty count. In the year 1834, a strong earthquake occurred, affecting the area. The count called Miklos Ybl, who was to become the most significant Hungarian architect, to reconstruct some of the landmarks, including churches (Fig. 2). This was the start of his career. The year 2014 was in Hungary the national Miklos Ybl year, but the works on today's territory of Romania, such as in and around Carei, are less known.

To accomplish this, a new method of mapping is necessary. Starting with Renaissance, the mapping methods of Nolli (the plan of Rome) are outstanding in the level of detail for representing strategic and common buildings. This can be well integrated into today's strategic planning, in which not all areas are treated equally, but depending on their strategic role. More recent mapping concepts in the physical space support this approach. Such are those from the 1960s: Kevin Lynch's approach (1960) and Guy Debord's derive (1955). They are relevant in reconstruction after disasters, in keeping the mental map of heritage habitat. This is a concept employed in the doctorate work of Bostenaru (2012), in the analysis of reconstruction after disasters of Modernist neighbourhoods. In this ongoing research, the mental map is given by the analysis of the settlement history of the villages around and the city of Carei (Fig. 3a), as well as by field investigation. In this way, landmarks (according to the method of Lynch, 1960) such as churches are recorded.

Approaching physical vulnerability in earthquake scenarios, the team around Lagomarsino (1998) proposed a methodology for monumental buildings, including churches. Studies on the impact 
of the 1834 Érmellék earthquake, which affected Carei, include the effect on common buildings (Zsíros, 1983), but studies on the records in churches in the area are remaining at the history of architecture stage (Bara, 2013). Other records are the church records, for example on which the work of Merli (2007) is based. The innovation compared to the main site in the project is the geographical scale of the investigation: instead of treating an urban area, it will deal with the regional scale of a city and the neighbouring villages, with typical Swabian houses (Fig. 2a). The zoom level will be given by landmarks such as churches and castles.

The 1834 earthquake has been put in context of the $19^{\text {th }}$ century photography of disasters investigated at the Canadian Centre for Architecture. For Romania, there aren't such depictions of the area. The $19^{\text {th }}$ century and the early $20^{\text {th }}$ photographers such as Carol Popp de Szathmary and Willy Pragher, the photographs of whom were useful in the analysis of Bucharest, or István Kováts, based in another region, have been considered from the photographers of the time.

During the stay in Karlsruhe, two aspects related to the development in Northwest Romania were studied:

1. The origin localities of the Swabians in South East Germany (Fig. 3). In the Upper Swabia (Oberschwaben) region an intense construction activity took place in the 18th century, generating what is called today the "Swabian baroque street". Places visited included some in the county of Ravensburg, namely Bad Schussenried with a remarkable library and Weingarten with a remarkable pilgership church. Through the existence of monumental church buildings from the time of the emigration, which define a cultural route which can be a mental map, a link is given to the churches in Sathmar. A research question is how far is pilgership connected to emigration.

2. The development of South West Germany in the 18th century. The host city of Karlsruhe was founded 1715 , celebrating 2015 its $300^{\text {th }}$ anniversary. Almost contemporarily, 1712, the Swabians started to emigrate to Western Romania. The count of Karlsruhe also gave rights to settle in the city (as documentation in exhibitions showed), and it is a question why immigration was chosen over the close settlement. In the city of Karlsruhe remarkable architecture was done as well, and documentation was made with exhibition, book and lecture about classicist architecture of Friedrich Weinbrenner.

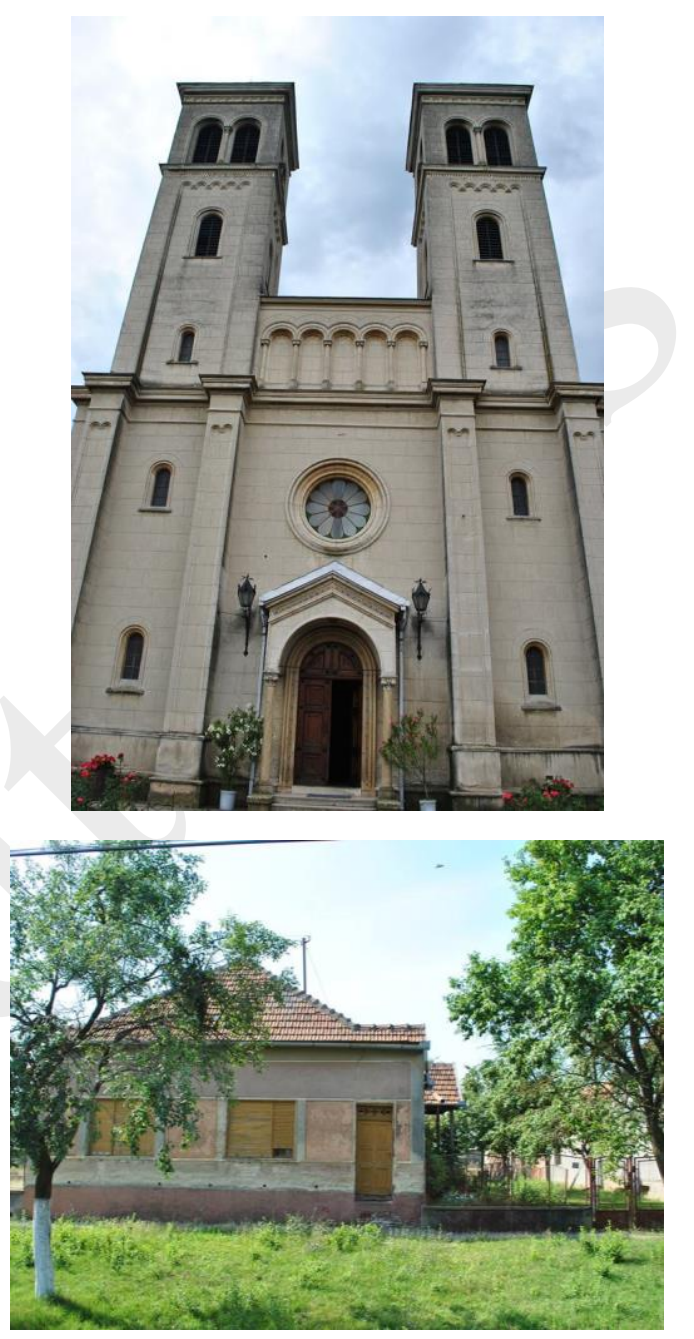

Figure 2a. The places of immigration of the Swabians: Typical vernacular Swabian building (bottom, report prepared for http://www.world-housing.net/) $2 b$ Church in Capleni, reconstructed by Ybl Miklos (top). Photos: M. Bostenaru, 2014.

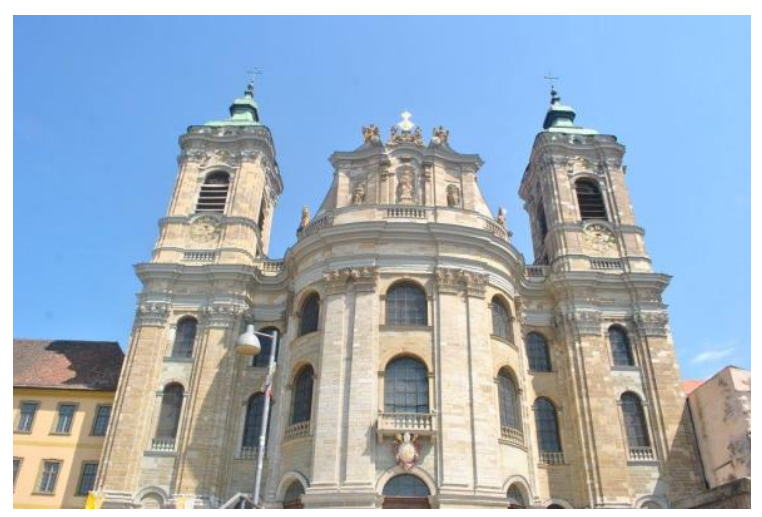

Figure 3. Baroque architecture in the places of origin of the Swabians: pilgrimage basilica in Weingarten. Photo: M. Bostenaru, 2015. 


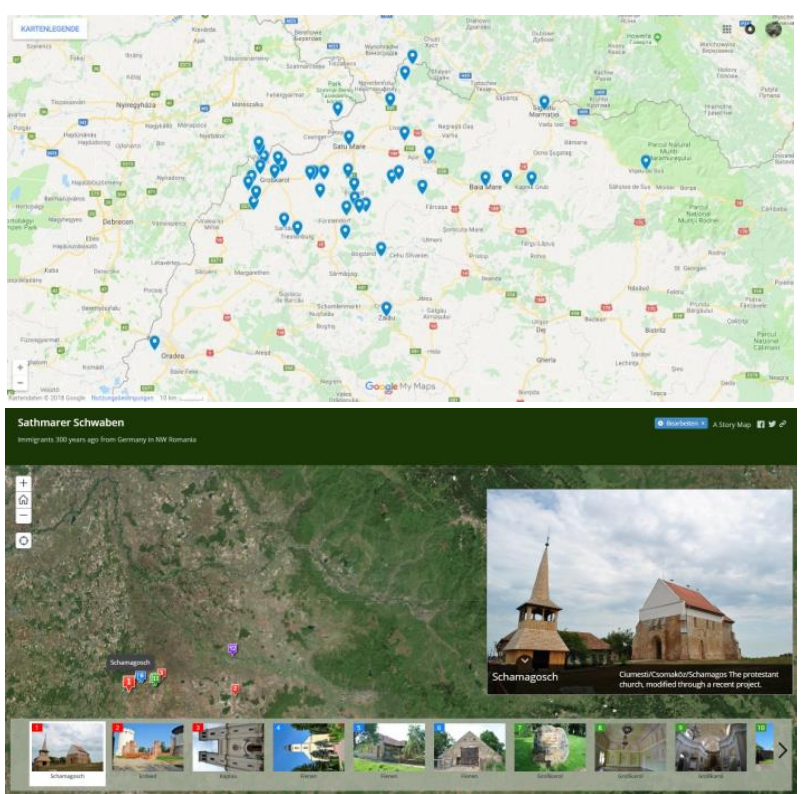

Figure 4a. Swabian localities of immigration in Sathmar county (top). Full map

https://www.google.com/maps/d/embed?mid=1VojsRwl

B1L94UsoziNgTxyQMVG-bzVuH. Same map on

ArcGIS fully available at https://arcg.is/1S099q

Figure $\mathbf{4 b}$. Story map of the Sathmar Swabian landmarks in Sathmar county in the localities visited so far in frame of the field trips (bottom). Full map at https://arcg.is/18nXyD

The routes of migration and the differences in architectural development in the two settlements (Fig. 4-6) are a good subject for psychogeographic representation such as in the approach of Guy Debord.

The method applied for mapping started to be developed by Bostenaru and Panagopoulos (2013) and was continued as a cooperation between Bucharest and Karlsruhe in 2014 and 2015 (Bostenaru and Dill, 2014) for the main test area. This research is a continuation of the initial model by Bostenaru and Panagopolos (2013), which investigated the impact of the 1755 Lisbon earthquake.

Reconstruction in Lisbon was classicist, not baroque, such as the buildings in Karlsruhe. In the context of the city celebrations, the research on the reconstruction of Lisbon post 1755 earthquake and its way of mapping (Bostenaru and Panagopoulos, 2014) could be discussed well at the site of the stay abroad in frame of the POSDRU project.

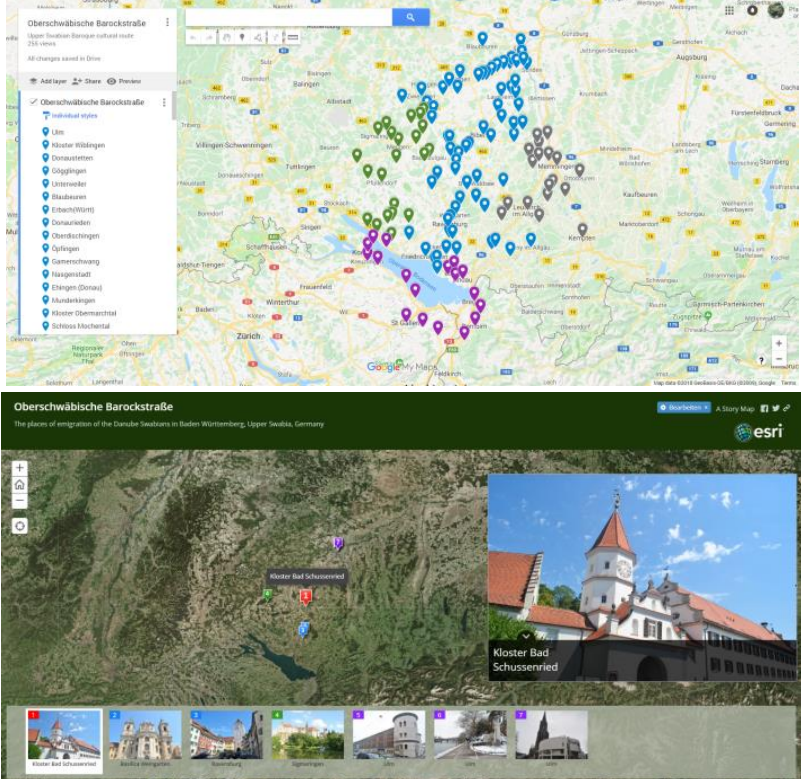

Figure 5a. Swabian places of emigration: The Upper

Swabian Baroque street (top). Full map

https://www.google.com/maps/d/embed?mid=1Opuf31R pffbWxlOSkijOP2vkPZ0aoJwc

Figure 5b. Story map of the Swabian localities visited so far (bottom). Full map https://arcg.is/jmeiv

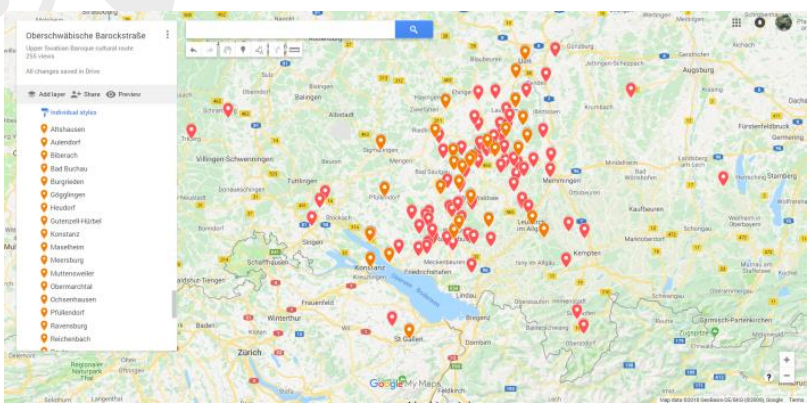

Figure 6. Swabian places of emigration:

Places of emigration with Baroque heritage (orange) and all places (rosa).

The relationship between the $18^{\text {th }}$ century Karlsruhe and the $18^{\text {th }}$ century Lisbon does not stop here. Before the 1755 earthquake, Swabian architect Johann Friedrich Ludwig designed the monumental complex of Mafra (monastery, basilica and royal palace) near Lisbon, which is related to a certain extent to the Upper Swabian complex of Wiblingen near Ulm (monastery with library such as the one in Bad Schussenried). After the 1755 earthquake, the basilica in Mafra served as a model to the basilica of Estrela in Lisbon, one of the landmarks included in the Bostenaru and Panagopoulos (2013) study. 
Upper Swabia is not only characterised by the presence of Baroque heritage built shortly before or during the time of emigration of the settlers which built the oldest cultural route of Germany, the Upper Swabian Baroque Street (Oberschwäbische Barockstraße). It is also characterised by the presence of notable rural heritage which permits us to compare another type of architecture in the places of origin as opposed to the places where the migrants settled. One item of rural heritage are the historical mills on the 10 years old Upper Swabian Mills Street (Mühlenstraße Oberschwaben) (Fig. 7). Such rural heritage is investigated and conserved in Romania by the ASTRA open air museum in Sibiu and got the golden medal at the Denkmal 2018 Leipzig for quality in conservation. The ASTRA open air museum, visited in frame of the research, features as "Street of ethnic minorities", funded by EEA grants, including a Swabian horse mill from Banat, but none of the heritage of Sathmar Swabians. In Germany, open air museums conserve rural heritage of Swabians in the past 3-5 centuries at three locations: Kürnbach (Bad Schussenried), Wolfegg and Illerbeuren (Fig. 8). By investigating this heritage (a study visit to Museum Kürnbach is planned, and literature was researched on the museums in Wolfegg and Illerbeuren) lessons can be learned on how the rural house changed with migration. In Sathmar, besides numerous houses conserved in situ (such as that in Fig. 2a), in Petrești a Swabian house has been transformed in a museum and a visit is planned.

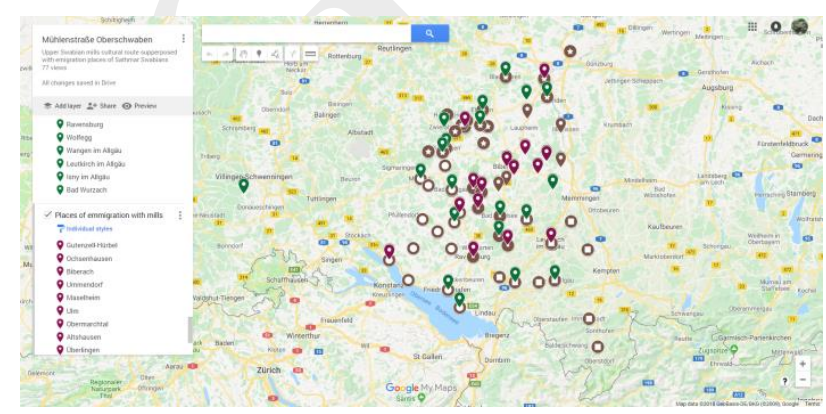

Figure 7. Oberschwäbische Mühlenstraße (Swabian cultural route of mills, brown), superposed to baroque heritage (green) and to places of emigration (purple). Full map here

https://drive.google.com/open?id=1drJnxBFNzh49sGf9T UjNyHblTrlQUpxF\&usp=sharing

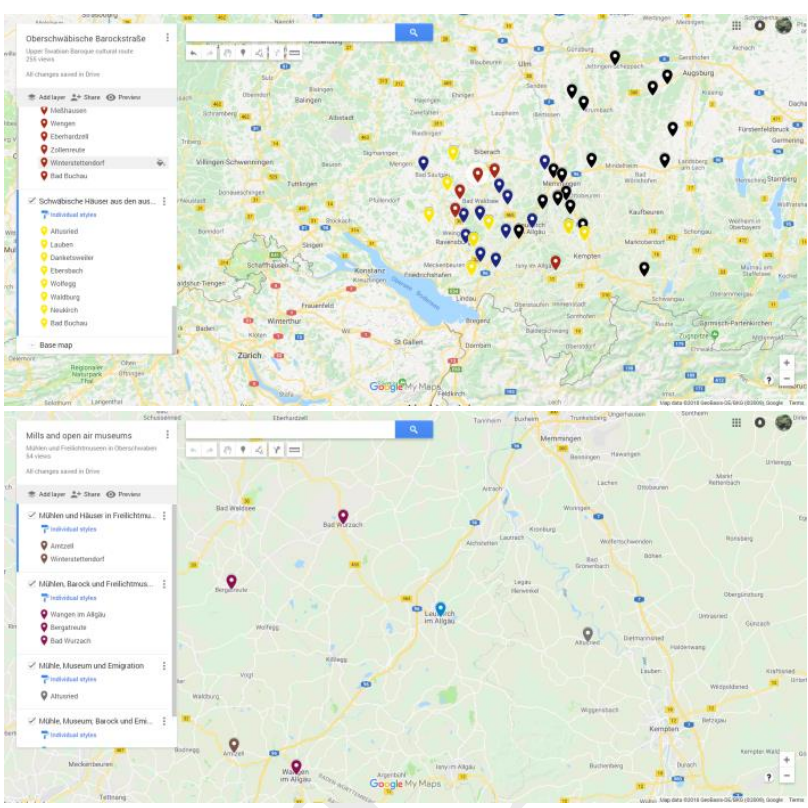

Figure 8a (top). Origin places of rural housing in open air museums on Swabian heritage: Museumsdorf Kürnbach (brown), Museum Wolfegg (blue),

Schwäbisches Bauernhofmuseum Bayern (black). With yellow are marked the localities from where also emigrants started.

Figure $8 \boldsymbol{b}$ (bottom) Places with baroque and mills heritage, and from where emigrants started. Full map at https://drive.google.com/open?id=1nnAJ_RS51oxYni80_ Lt8SvsA7Z6SpW7J\&usp=sharing

Looking to the maps it can be observed that while numerous locations of emigration display Baroque or mill heritage or both, numerous ones also do not display this. From here we draw the conclusion that the settlers came from localities with more or less wellbeing.

\section{SPECIFIC OBJECTIVES}

The research about landmarks contributed to the main objective of the POSDRU postdoctoral project, concluded at the University of Bucharest. The dynamic of migration is one of the approaches to be followed in the future, and the landmarks identified can be investigated with the mean of psychogeography like it was done in the main site considered in the POSDRU project (Magheru Boulevard in Bucharest).

From the specific objectives of the Swabian migration project the one which involves looking into the elements of selected monumental buildings 
such as churches at a bigger scale, and classifying them into elements, in ontology, contributed to the decision system to be developed. This will be the subject of a future paper. In the case study investigated in this paper it is about the simulation of a historical decision of movement of populations which could chose between a city like Karlsruhe, built at that time, and the location in Sathmar, given that financial incentives were given for both. Another objective of the project aimed to define a methodology of economics efficiency of risk mitigation in the urban areas and the building structure. In the future, we need to calibrate our models considering real examples, from the archives or from today (the later through contacts with offices). At the same time, the implication of methods from game design allows us to translate the resources needed for the building into such resources which can be taken in consideration in agent-based design (ex. device planning). In a city building game each construction is built using stylised quantities of different types of resources (brick, wood, etc.), same as for board games which suppose building something. In the approach of Bostenaru (2004) a similar method was employed for economic studies. Based on the civil engineering method of calculation, device tables were defined, including certain types of materials and of works to be performed in order to build, repair or retrofit. These devices depend only on working time and material quantities, but not on the characteristics of the market regarding salaries and material prices at a certain location. This way they can be adapted to different countries, by adding the monetary value, also for those where there are not yet databases of seismic retrofit works, as in Romania. Such databases would have been necessary for other methods.

\section{MATERIALS AND METHODS}

For a project regarding cross border migration 300 years ago, the multicultural context is important to be understood. In this context, several methods were used to perform the investigation:

- Field trip to the Swabian Baroquestreet, and the reference of related books and brochures.
- Visiting the exhibitions showing the $18^{\text {th }}$ century background of the city of Karlsruhe, such as the one on the court of count Karl Wilhelm of Baden, the Weinbrenner architecture and the city of Karlsruhe in photography, combined with the consultation of different catalogues (Kleinmanns 2014, SAAI, 2015). The architect Weinbrenner spent some time in Rome, shortly after the time Nolli and Piranesi had drawn their innovative maps, and it is interesting to follow the lessons learned from this approach during Baroque Rome in his Classicist urban planning.

- Attendance of a lecture on the founding phase of the city of Karlsruhe and connected discussion with a sociology professor.

- Discussion with librarians on the book of digitally modelling the impact of the 1755 Lisbon earthquake.

- Visit to exhibitions at ZKM and exhibitions organised by ZKM in the city related to the anniversary of Karlsruhe: "The global", with digital means. Discussion with experts involved.

A literature review on materials prepared for the $300^{\text {th }}$ anniversary of Karlsruhe, and collected during the field stay there, in frame of the POSDRU project, was performed. Preliminary literature research took place in July and August 2014, with the results being systematized in September-October 2014, as well as in June 2015.

\section{RESULTS AND OUTLOOK}

Towards the mentioned specific objectives, simulation of settlement structures through games (the chronological development of productive processes through the years for more households) allowed for the complex network analysis of the actors involved in decision. We run such a game for the hazard of drought in agriculture, based on the Green Revolution game (Chapman, 1973). This simulation does not include the spatial dimension, but efforts at the Ohio State University (Ahlqvist, 2011) have included GIS to create a landscape of the game. With these efforts made, the simulation goes into rural dimension. The landmarks developed in Lynch's (1960) concept are applicable to this type of geographic space as well. 
In frame of the DOMUS project, the author participated in a workshop organised in frame of the Urban Eye film festival on psychogeographic investigation of Bucharest called "Playing Bucharest" (http://urbaneye.ro/event/playingbucharest/). In frame of the workshop led by Karsten Michael Drohsel, the author participated in the creation of a new game which supposes the movement of items related to buildings from one location to another. The starting idea was the plastering of buildings, but these items can be anything what can be then shared. The game can be adapted to the migration topic considered in this article, seeing which features of churches (the landmarks) or of peasant construction were taken by the settlers across time and space.

Current research investigates the typical peasant houses (such as the Museum house in Petresti, Sathmar county) or the peasant museums (such as the one in Bad Schussenried, in Bucharest, in Sighetu Marmatiei or in Sibiu - the Astra Museum). The way of living of the typical household is important in modelling the structure and the relevant elements for the economic simulation in the game. For the open-air museum in Kürnbach/Bad Schussenried see Schmid (1976).

Figure 9 shows the zoom between scales from the map of the emigration places in the region, to the rural zone and the typical Swabian house in Romania (which is to be investigated how much it relates to the one in Germany).

Our efforts in this direction focus on the area of Sathmar county, for which we have records of settlement of peasants (Vonház, 1987), but also of the earthquake striking in 1834. Following the earthquake, the most important Hungarian architect, Miklos Ybl was employed to restore churches (ex. in Căpleni village). The archive records on the damages to churches (from art history studies, for example, Bara 2013, to name just one) can serve to establish earthquake intensity with the mentioned macro-element method (Lagomarsino, 1998), in dialogue with the seismologic studies. For example, Zsíros (1983) established the intensity based on the level of failure of common buildings out of different materials (Fig. 2). Similar recording of the states after each game round could be applied for other board games based on the city building games principles where disasters can strike (ex. SimCity for different disasters, including the 1906 San Francisco earthquake, World without End for the pest).

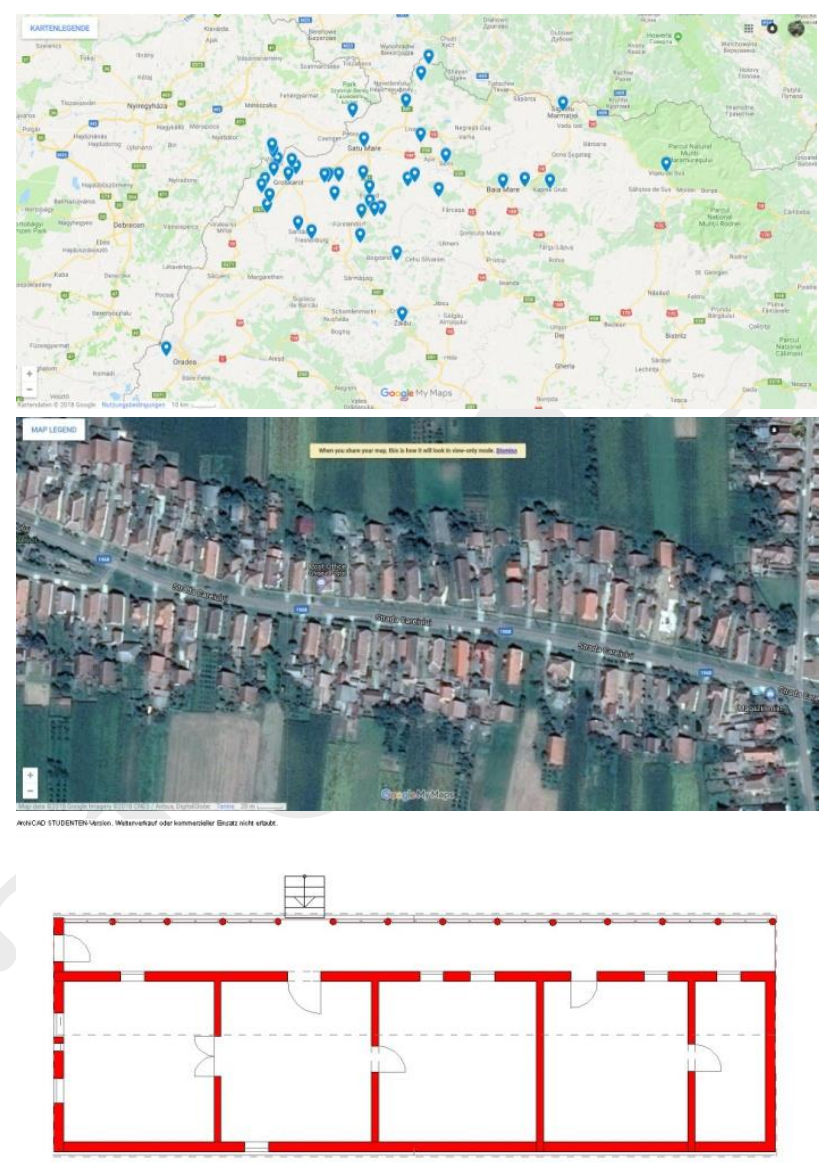

Figure 9. The scale zooms from region to building on the example of a typical Swabian house (see fig. 1a) in Foieni, Romania.

Through the research in Karlsruhe we learned more about the history, geography and architecture of the period, and can better compare both geographic locations as well as the migration between them. Perspectives for future research opportunities are opened.

From game theory a next step can be done to drama theory (employing conflict manager software) and to analytic hierarchy in decision instead of decision tree. By these means, qualitative issues are preferred, but we need to consider that datascapes are built on quantitative aspects. Datascapes are 3D models of GIS plotted into Google Earth, where the height dimension is replaced by plotting data connected to different characteristics of the building. In an attempt to 
consider such different qualitative characteristics of the buildings (for example the function of the building) data from GIS are interpreted for datascapes based on their agent-based modelling role - for example, the landmarks and strategic elements serve a certain area of a residential zone. From the measurement spaces employed for criteria at building level (Bostenaru, 2006) we go thus to measurement spaces for the urban datascapes through regression, which means using induction and deduction, around a hypothesis. The construction of economic regression method supposed the following:

- Based on case studies, we began to draw knowledge about interest groups (the actors in the decision process).

- We built a hypothesis concerning the functional structure of decision making.

- We stated goals for each actor and on each level of intervention, from urban level over building level up to the building macroelement.

- Statements on the value of the criteria to be measured were derived.

In a first methodological step, at urban level we assigned weights to the attributes of a building in GIS representing the central Bucharest site (Magheru area, Fig. 1 top). These attributes can be connected through ontology or a complex network for translation into an exploitable foreground for a computer system. In the Magheru case, the difference was given by the state of the building before the earthquake, after the earthquake and after rebuilding, rebuilding which may happen before the next earthquake. This was represented in photographs, and the complex network referred to the characteristics of the images. In case of the sites in Sathmar and Upper Swabia, the complex network connections are given by the social networks of migration, namely from which city to which city did the settlers move. The origin localities and the new settlements in Romania were mapped in the figures according to Vonház (1987).

The envisaged result will be a map including the methods of Nolli, Lynch and Debord.

The land of Baden-Württemberg in Germany, where Karlsruhe is located, is rich in institutions researching the heritage of German minorities in
Eastern Europe in general, and in Romania in particular. Such ones are the Haus of Donauschwaben (House of the Danube Swabians) in Sindelfingen (one of more of this type), Institut für Donauschwäbische Geschichte und Landeskunde (Institute for Danube Swabian history and geography), Donauschwäbisches Zentralmuseum Ulm (Central Museum for Danube Swabians in Ulm) and Institut für Volkskunde der Deutschen des östlichen Europa (Institute for research of the Germans in Eastern Europe), all dealing with Danube Swabians. They expressed interest in the results of this research. In the future it is possible to do research on the topic in their image archives and their rich libraries, also involving the Danube Swabians localities in the home country.

\section{ACKNOWLEDGEMENTS}

This work was supported by the strategic grant POSDRU/159/1.5/S/133391, Project "Doctoral and Post-doctoral programs of excellence for highly qualified human resources training for research in the field of Life sciences, Environment and Earth Science" financed by the European Social Found within the Sectorial Operational Program Human Resources Development 2007 - 2013". The specific part presented in this paper was performed during the stage abroad hosted by the Geophysical Institute of the Karlsruhe Institute of Technology, prof. dr. Friedemann Wenzel (August 2015). The work is now funded by a DOMUS scholarship of the Hungarian Academy of Sciences DSZS2018-9 (September 2018-March 2019).

\section{REFERENCES}

Ahlqvist, O. (2011). Converging Themes in Cartography and Computer Games', Cartography and Geographic Information Science 38: 278-285.

Bara, J. (2013). Patronajul artistic al familiei Károlyi în Carei și împrejurimi în secolul XVIII, Universitatea Babeș-Bolyai Facultatea de istorie și filosofie Școala doctorală "Istorie, civilizaţie, cultură" lucrare de doctorat.

Bostenaru Dan, M. (2004). Economic Efficiency and Applicability of Strengthening Measures on Buildings for Seismic Retrofit. An action guide, International Conference, Disasters and Society - From Hazard 
Assessment to Risk Reduction', 26-27 July 2004, Karlsruhe, Germany, in: Malzahln, D and Plapp, T (eds) Disasters and Society - From Hazard Assessment to Risk Reduction, Logos Verlag, Berlin, 2004, pp. 289-296.

Bostenaru Dan, M. (2006). Regression based criteria determining for preservation strategies of early $\mathrm{RC}$ buildings, in: Proceedings of the 2 nd fib Congress (Napoli, Italy, 5-8 June 2006), (CD), article \#0013, Extended abstract published in volume 2 of the proceedings, fib Italia, Napoli, pp. 788-789.

Bostenaru Dan, M. (2012). Arhitecturainterbelică cu structură din betonarmatexpusă la hazard seismic în context european. Intervenţiiînspaţiulromanesç̧iitalian, Universitatea de Arhitecturăși Urbanism „Ion Mincu“, Școaladoctorală SITT, teză de doctorat.

Bostenaru Dan, M. (2014). Mapping of earthquake impact at different geographic scales (building and urban zones) in the urban and rural area: the impact of the 1977 (Vrancea) earthquake on the central zone of Bucharest and of the 1834 (Érmellék) earthquake on the zone in and around Great Carei, presented 3rd of October 2014, Bucharest, at the INCD URBANINCERC conference.

Bostenaru Dan, M. and Armas, I. (2015). Earthquake impact on settlements: the role of urban and structural morphology, Nat. Hazards Earth Syst. Sci., vol. 15, pp. 2283-2297

Bostenaru Dan, M. and Dill, A. (2014). ,Spatial Street Network and Urban Routes Around the Modernist Boulevard in Bucharest', in Crăciun, C and Bostenaru Dan, $\mathrm{M}$ (eds) Planning and designing sustainable and resilient landscapes, Springer, Dordrecht, pp. 187-217.

Bostenaru Dan, M. and Panagopoulos, T. (2013). Digital modeling of the impact of the 1755 Lisbon earthquake, "Ion Mincu" Publishing House, Bucharest.
Chapman, G.P. (1973).The green revolution: a gaming simulation', The Royal Geographical Society (with the Institute of British Geographers), 5: 129-140

Debord, G. (1955). Introduction to a critique of urban geography. in: Knabb, K (ed.) Situationist International Anthology, 532, Bureau of Public Services, Berkeley, CA.

Städtische Gallerie Karlsruhe, SAAI (2015). Friedrich Weinbrenner 1766-1826 Architektur und Städtebau des Klassizismus, Michael Imhof Verlag, Petersberg

Kleinmanns, J. (ed.) (2014). Die Kunstdenkmäler der Stadt Karlsruhe : der Stadtbau und der Schlossbezirk / bearb. von Arthur Valdenaire. Imhof, Petersberg.

Lagomarsino, S. (1998). A new methodology for the post-earthquake investigation of ancient churches, 11th European Conference on Earthquake Engineering 1998 Balkema, Rotterdam

Lynch, K. (1960). The Image of the City, MIT Press, Cambridge MA.

Nolli Urban plan of Rome http://nolli.uoregon.edu/

Merli, R. (2007). DonauschwäbischeOrtschaften in NordwestSiebenbürgen, Selbstverlag, Bubenheim.

Schmid, H. (1976). Das oberschwäbische Bauernhaus und seine Darstellung im Freilichtmuseum Kürnbach, Denkmalpflege in Baden-Württemberg, https:// journals.ub.uni-heidelberg.de/index.php/ nbdpfbw/article/viewFile/14610/8483.

Sitte, C. (2002). Der Städtebau nach seinen künstlerischen Grundsätzen, Birkhäuser, Basel.

Vonház, S. (1987). Die deutsche Ansiedlung in Komitat Sathmar, Laupheim.

Zsíros, T. (1983). The Érmellék earthquake of 1834, Acta Geodaet., Geophys., Hung., vol. 18, pp. 129-134. 